\title{
BIOACTIVE MIXED LIGAND METAL COMPLEXES OF Cu(II), Ni(II), AND Zn(II) IONS: SYNTHESIS, CHARACTERIZATION, ANTIMICROBIAL AND ANTIOXIDANT PROPERTIES
}

\author{
MD. ASHRAFUZZAMAN ${ }^{1}$, FARZANA KHANM CAMELLIA ${ }^{1}$, ABDULLAH AL MAHMUD ${ }^{1}$, MD. JOY PRAMANIK ${ }^{2}$, \\ KAMRUN NAHAR ${ }^{2}$, MD. MASUQUL HAQUE ${ }^{1}$ AND MD. KUDRAT-E-ZAHAN ${ }^{1 *}$ \\ ${ }^{I}$ Department of Chemistry, University of Rajshahi, Rajshahi-6205, Bangladesh. \\ ${ }^{2}$ Department of Genetic Engineering and Biotechnology, University of Rajshahi, Rajshahi-6205, Bangladesh.
}

\begin{abstract}
A series of transition metal complexes having general formula $[\mathrm{M}(\mathrm{L} 1)(\mathrm{L} 2)]\left(\mathrm{NO}_{3}\right)_{2}$, (where, $\mathrm{M}=\mathrm{Cu}(\mathrm{II}), \mathrm{Ni}(\mathrm{II})$, and $\mathrm{Zn}$ (II)) of mixed ligands, $\mathrm{L} 1=\mathrm{Isonicotinamido}-$ Thiophene-2-Carbaldimine, L2 = 1, 10-phenanthroline, were synthesized. The obtained compounds were successfully characterized by different spectroscopic techniques. Conductivity measurements indicated that all complexes were 1:2 electrolytes in nature. IR spectra indicated that ligands coordinated to metals via the carbonyl oxygen atom and the azomethine nitrogen atom. Magnetic moment values and UV-Visible spectra confirmed square planar structure around the Cu(II), and $\mathrm{Ni}(\mathrm{II})$ ions, and a tetrahedral geometry around the $\mathrm{Zn}(\mathrm{II})$ ion.The metal complexes were tested against Escherichia coli and Pseudomonas sp. Among the tested compounds, Zn(II)complex showed higher antibacterial activity over both bacterial strains against reference drug Kanamycin. Moreover, synthesized metal complexes exhibited moderate antioxidant activity than the Schiff base. $\mathrm{Cu}$ (II) complexes were found to be most active whereas, $\mathrm{Zn}$ (II) complexes showed the lowest antioxidant activity comparable to the BHT.
\end{abstract}

Keywords: Transition metal complexes, Schiff Base, 1, 10-Phenanthrolin, Antimicrobial, Antioxidant properties.

\section{INTRODUCTION}

A German chemist and physicist Hugo Schiff first synthesized Schiff bases which are compounds containing azomethine ( $-\mathrm{C}=\mathrm{N}-)$ group. Schiff bases, which are usually prepared by the condensation of primary amines and active carbonyl groups such as aldehydes or ketones [1-3]. They are topflight coordinating ligands and form stable complexes with various transition metal ions [4]. Aswell, Schiff -base is a fascinating class of ligands that have played significant acting in the betterment of coordination chemistry. Schiff -bases and their complexes have a diversity of applications in the biological activity studies and industry [5-10] to they are used radiotracers in nuclear medicine and drugs [11]. Moreover, Schiff-bases are extremely momentous substances for inorganic chemists as these are generally used in medicinal inorganic chemistry because of their various biological, pharmacological, antitumor activities as well as their outstanding chelating ability [12].

Furthermore, they have potential applications in many other fields such as biological (including antibacterial, antifungal, anti-oxidative anti-inflammatory, anti-tumor, anti-cancer, and anti-HIV), optical materials, chemical sensor, clinical, analytical, and electrochemistry [13-18]. Mixed ligand complexes have a major role in the biological field as shown by several ways in which metal ions activate enzymes. Schiff bases, for example, derived from heterocyclic compounds, P- anisaldehyde and furan- 2-carbaldehyde have attracted keen interest in biological chemistry [19-21]. Iso-nicotinylhydrazide (INH) is a biocompound that is one of the most powerful drugs and medicines of the first-line for the treatment and the prevention of tuberculosis. Because of the high antibacterial activity of this compound against Mycobacterium tuberculosis, the World Health Organization (WHO) considers INH asa standard treatment material. It forms metal chelate compounds with different bivalent ions having moderate to significant biological importance [22-25]. In the present paper, we report the results on the synthesis, characterization and antibacterial and antioxidant activities of transition metal complexes of $\mathrm{Cu}(\mathrm{II}), \mathrm{Ni}(\mathrm{II})$, and $\mathrm{Zn}$ (II) ions containing thiophene-2-carbaylidene-isonicotinohydrazone Schiff base and 1, 10-Phenanthroline ligand.

\section{EXPERIMENTAL METHODS}

The weighing operation was performed with the help of a METTLER PM 200 electronic balance. The melting or decomposition temperatures of all the prepared metal complexes were observed in an electro thermal melting point apparatus model o.AZ6512. Infrared spectra of the ligands and complexes were recorded on a FTIR-8400, SHIMADZU, Japan using a $\mathrm{KBr}$ disc at the Central Science Lab of Rajshahi University. The Electronic spectra of the complexes in solution phase $\left(1 \times 10^{-5} \mathrm{M}\right)$ were recorded in the range of $200-800 \mathrm{~nm}$ on a
Thermo-electron Nicolet evolution 300 UV-Vis spectrophotometer. Conductivity measurements of the complexes were carried out in $N, N^{\prime}$ dimethylformamide (DMF) using Horiba conductivity meter B173 in which cell constant is fixed. Sherwood Scientific Magnetic Susceptibility Balance was used to measure the magnetic moment values. Elemental analysis was carried out on a LECO (CHNS-932) elemental analyzer. The purity of all these compounds was tested by thin layer chromatography (TLC) on Silica gel-GF 254 (Merck) coated plates.

2.1. Synthesis of thiophene-2-carbaylidene-isonicotinohydrazone Schiff base, ligand(L1)

Thiophene-2-carbaylidene-isonicotinohydrazone Schiff base Ligand was prepared (Scheme 1) by the condensation reaction (refluxed for 5 hours) of isoniazid (INH) $(1.374 \mathrm{~g}, 10.00 \mathrm{mmol})$ and thiophene-2-carbaldehydein $(0.93$ $\mathrm{mL}, 10.00 \mathrm{mmol})$ in an equimolar ratio $(1: 1)$. The color of the solution (brown) converted into white by this time. The completion of the reaction was monitored by TLC. Eventually, it produced a white crystalline solid which was filtered off and dried in a desiccator over anhydrous $\mathrm{CaCl}_{2}$.

\section{Thiophene-2-carbaylidene-isonicotinohydrazone}

$\mathrm{C}_{11} \mathrm{H}_{9} \mathrm{~N}_{3} \mathrm{OS}$; White solid, yield $88 \%$, mp., $210{ }^{0} \mathrm{C}$, IR spectrum, $v, \mathrm{~cm}^{-1}$ : 1665.57 $(\mathrm{C}=\mathrm{O}), 1595.57(\mathrm{C}=\mathrm{N})$. UV-Vis spectrum, $\lambda_{\max }, \mathrm{nm}: 271$, 324. Elemental analysis for $\mathrm{C}_{11} \mathrm{H}_{9} \mathrm{~N}_{3} \mathrm{OS}$ : Found, \%: C, 57.13; H, 3.92; N, 18.17; O, 6.93; S, 13.86. Calculated, \%: C, 57.08; H, 3.89; N, 18.16; O, 6.92; S, 13.84

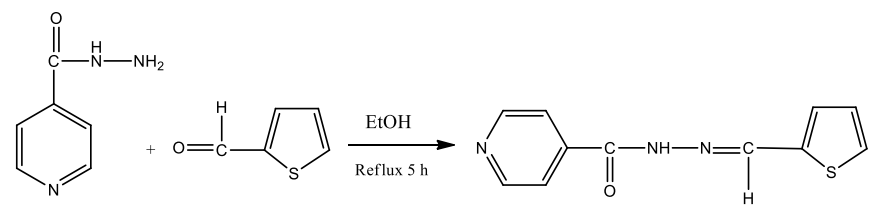

Scheme 1. Synthesis of Schiff base, thiophene-2-carbaylideneisonicotinohydrazone (L1).

\subsection{Synthesis of Mixed Ligand Complexes}

The synthesized Schiff base ligand L1 $(0.232 \mathrm{~g}, 1 \mathrm{mmol})$ was dissolved in methanol $(10 \mathrm{~mL})$. Then, the hot methanolic solution of ligand and equimolar 1,10-phenanthroline hydrate $(0.198 \mathrm{~g}, 1 \mathrm{mmol})$ were added up drop-wise unitedly in the heated methanolic solutions $(10 \mathrm{~mL}, 1 \mathrm{mmol})$ of nitrate salts $(0.254 \mathrm{~g}$, $1 \mathrm{mmol})$ of metals for-instance; $\mathrm{Cu}(\mathrm{II}), \mathrm{Ni}(\mathrm{II})$, and $\mathrm{Zn}$ (II). The mixture was 
refluxed for 4 hours and after completion of the reaction, it allowed to cool slowly (Scheme 2). The obtained precipitate was filtered, washed with a-few times with methanol, and dried under vacuum on anhydrous $\mathrm{CaCl}_{2}$. The synthesized metal complexes were soluble in dimethyl sulfoxide (DMSO) and $\mathrm{N}, \mathrm{N}$ dimethylformamide (DMF).

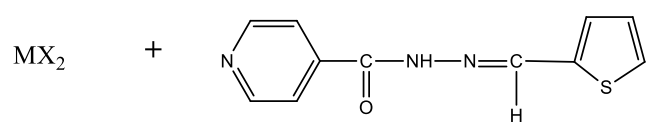

L1

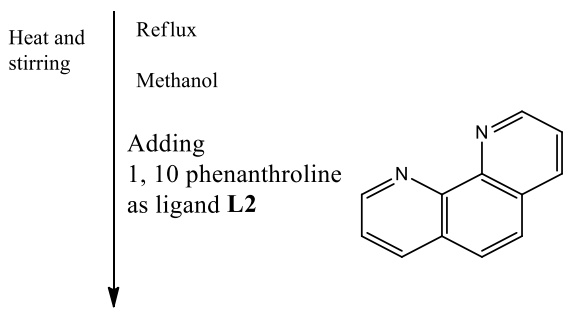

$[\mathrm{M}(\mathrm{L} 1)(\mathrm{L} 2)] \mathrm{X}_{2}$

Scheme 2. Synthetic pathway of mixed ligand complexes, Where, $\mathrm{M}=$ $\mathrm{Cu}(\mathrm{II}) / \mathrm{Ni}(\mathrm{II}) / \mathrm{Zn}$ (II) ions.

\section{$\left[\mathrm{Cu}(\mathrm{L1})(\mathrm{L} 2]\left(\mathrm{NO}_{3}\right)_{2}\right.$ :}

[CuC ${ }_{23} \mathrm{H}_{17} \mathrm{~N}_{7} \mathrm{O}_{7} \mathrm{~S}$ ]; F.wt.(g/mol): 599.03; Yield: 79\%; Color: Dijon yellow solid, mp., $258^{\circ} \mathrm{C}$. Molar conductance $\left(\Omega^{-1} \mathrm{~cm}^{2} \mathrm{~mol}^{-1}\right)$ : 137 . $\mu_{\text {eff }}$, B.M: 1.84 . IR spectrum, $v, \mathrm{~cm}^{-1}: 597.74(\mathrm{M}-\mathrm{N}), 681.89(\mathrm{M}=\mathrm{O}), 1595.05(\mathrm{C}=\mathrm{N}), 1636.29$ $(\mathrm{C}=\mathrm{O})$. UV-Vis spectrum, $\lambda_{\max }, \mathrm{nm}: 272,358,373$. Elemental analysis for $\mathrm{CuC}_{23} \mathrm{H}_{17} \mathrm{~N}_{7} \mathrm{O}_{7} \mathrm{~S}$; Found, \%: C, 46.12; H, 2.86; N, 16.37; O, 18.70; S, 5.35; Cu, 10.61. Calculated, \%: C, 46.07; H, 2.84; N, 16.36; O, 18.70; S, 5.34; Cu, 10.60.

\section{$[\mathrm{Ni}(\mathrm{L1})(\mathrm{L2})]\left(\mathrm{NO}_{3}\right)_{2}$ :}

[ $\left.\mathrm{NiC}_{23} \mathrm{H}_{17} \mathrm{~N}_{7} \mathrm{O}_{7} \mathrm{~S}\right]$ :F.wt.(g/mol):594.18; Yield: 62\%; Color:Crimson solid, mp., $241^{\circ} \mathrm{C}$. Molar conductance $\left(\Omega^{-1} \mathrm{~cm}^{2} \mathrm{~mol}^{-1}\right): 150 . \mu_{\text {eff }}$, B.M: 1.23 . IR spectrum, $v$, $\mathrm{cm}^{-1}: 596.20(\mathrm{M}-\mathrm{N}), 677.23(\mathrm{M}=\mathrm{O}), 1592.18(\mathrm{C}=\mathrm{N}), 1636.11(\mathrm{C}=\mathrm{O})$. UV-Vis spectrum, $\lambda_{\max }, \mathrm{nm}$ : 269 , 360.Elemental analysis for $\mathrm{NiC}_{23} \mathrm{H}_{17} \mathrm{~N}_{7} \mathrm{O}_{7} \mathrm{~S}$; Found, \%: C, 46.49; H, 2.88; N, 16.50; O, 18.85; S, 5.40; Ni, 9.88. Calculated, \%: C, 46.45; $\mathrm{H}, 2.86 ; \mathrm{N}, 16.49$; O, 18.85; S, 5.39; Ni, 9.88 .

\section{$\left[\mathrm{Zn}(\mathrm{L1})(\mathrm{L2}]\left(\mathrm{NO}_{3}\right)_{2}\right.$ :}

[ $\mathrm{ZnC}_{23} \mathrm{H}_{17} \mathrm{~N}_{7} \mathrm{O}_{7} \mathrm{~S}$ ]: F.wt.(g/mol): 600.87; Yield: 67\%; Color:White solid, mp., $251^{\circ} \mathrm{C}$. Molar conductance $\left(\Omega^{-1} \mathrm{~cm}^{2} \mathrm{~mol}^{-1}\right)$ : 143. $\mu_{\text {eff }}$, B.M: 0.75. IR spectrum, $v$, $\mathrm{cm}^{-1}: 592.20(\mathrm{M}-\mathrm{N}), 685.01(\mathrm{M}=\mathrm{O}), 1585.59(\mathrm{C}=\mathrm{N}), 1664.63(\mathrm{C}=\mathrm{O})$. UV-Vis spectrum, $\lambda_{\max }, \mathrm{nm}: 282,327$, 384. Elemental analysis for $\mathrm{ZnC}_{23} \mathrm{H}_{17} \mathrm{~N}_{7} \mathrm{O}_{7} \mathrm{~S}$; Found, \%: C, 45.97; H, 2.85; N, 16.32; O, 18.64; S, 5.34; Zn, 10.88. Calculated, $\%:$ C, 45.93; H, 2.83; N, 16.31; O, 18.64; S, 5.33; Zn, 10.88 .

\section{RESULTS AND DISCUSSION}

All complexes were insoluble in polar solvent but soluble in DMSO and DMF. The molar conductance values for all synthesized complexes were measured (10$\left.{ }^{3} \mathrm{M}\right)$ in DMF solvent at room temperature. Based on conductance measurements, all complexes were electrolytic nature and nitrate complexes were 1:2 electrolytes [26, 27]. For $\mathrm{Cu}(\mathrm{II})$, and $\mathrm{Ni}(\mathrm{II})$ complexes, magnetic moment values were 1.84 , and 1.23 B.M respectively indicating paramagnetic, and diamagnetic nature. These values correspond to square planar geometry and on the other hand, tetrahedral structure for Zn(II) ion complex with 0.69 B.M [28-31].

\section{IR Spectral Studies}

The $\mathrm{v}(\mathrm{C}=\mathrm{O})$ and $\mathrm{v}(\mathrm{C}=\mathrm{N})$ stretching bands are observed at $1666 \mathrm{~cm}^{-1}$ and 1596 $\mathrm{cm}^{-1}$, respectively (Figure I) in the IR spectrum of the Schiff base ligand [34, 35]. This band $\left(1666 \mathrm{~cm}^{-1}\right)$ in IR spectra of metal complexes was shifted to lower frequencies and displayed in the region $1636-1665 \mathrm{~cm}^{-1}$, indicating bonding of oxygen to the metal ions (Figure 1). Due to $\mathrm{M}-\mathrm{O}$ stretching vibrations the new absorption bands are at $677-686 \mathrm{~cm}^{-1}$ in the IR spectra of complexes [34-36].

The medium-strong band at $1596 \mathrm{~cm}^{-1}$ in spectrum of free Schiff base ligand is assigned to the azomethine $\mathrm{v}(\mathrm{C}=\mathrm{N})$ band. Comparison of azomethine stretch of the ligand with spectra of complexes appeared shift towards lower wavenumbers from $1585-1595 \mathrm{~cm}^{-1}$ region. These shifts suggested that ' $\mathrm{N}$ ' of the $\mathrm{C}=\mathrm{N}$ group coordinated to metal ions. In addition, the other bands appeared at $592-598 \mathrm{~cm}^{-}$ ${ }^{1}$ in the IR spectra because of $v(\mathrm{M}-\mathrm{N})$ vibration [36-39]. A strong sharp band of the IR spectra of mixed ligand complexes showed at $1384 \mathrm{~cm}^{-1}$ that can be attributed to an uncoordinated nitrate ion [27]

Thus, FT-IR spectra data confirms that two ligands coordinated to metal ions through the $\mathrm{C}=\mathrm{N}$ and $\mathrm{C}=\mathrm{O}$ groups respectively.

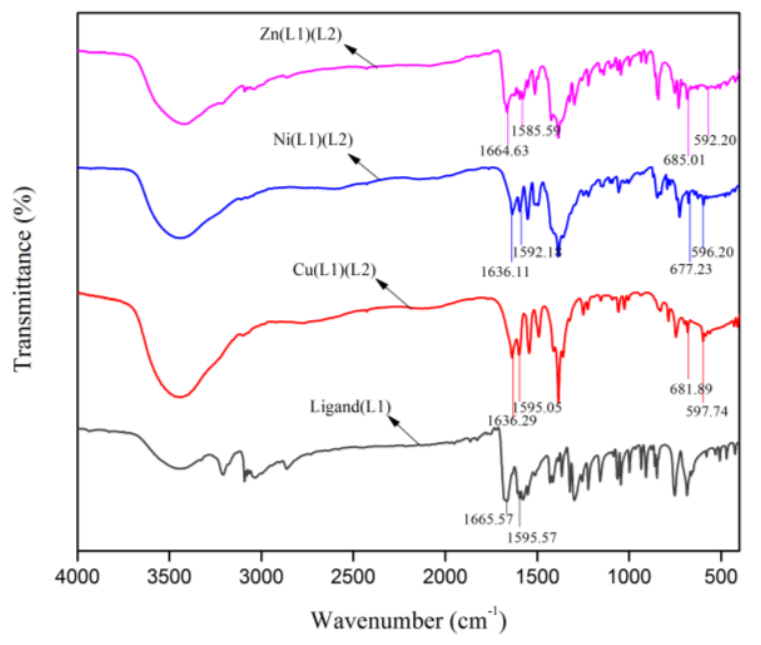

Figure 1. IR Spectra of the ligand L1, and its Mixed Ligand Complexes.

\section{UV-VisibleSpectra}

The electronic spectra of L1 (Fig. 2) demonstrated two absorption bands at 271 and $324 \mathrm{~nm}$, attributable to $\pi-\pi^{*}$ and $n-\pi^{*}$ transitions, respectively [40]. In case of the metal complexes, these transitions have been tested, shifts to longer and lower wavelengths and it verified the ligand to metal charge transfer (LMCT) and vice versa [31]. The $\mathrm{Cu}(\mathrm{II})$ complex electronic spectrum showed 272, 358, and $373 \mathrm{~nm}$ of absorption bands that could be assigned to $\pi-\pi^{*}, \mathrm{n}-\pi^{*}$, and charge transfer band (C.T) [41]. There are three strong bands at 282, 327, and $384 \mathrm{~nm}$ in the $\mathrm{Zn}$ (II) complex The peaks of 263 , and $327 \mathrm{~nm}$ are attributable to $\pi-\pi^{*}$, and $\mathrm{n}-\pi^{*}$, the absorption band of $386 \mathrm{~nm}$ is assigned to metal-ligand charge transfer (MLCT) [41-43]. In Ni(II) complex two peaks positioned at 269, and $360 \mathrm{~nm}$ are due to $\pi-\pi^{*}$, and charge transfer transitions, respectively [41]. Thus, the magnetic moment values along with electronic spectra data confirmed the square planar structures of $\mathrm{Cu}$ (II) and $\mathrm{Ni}$ (II) complexes and the tetrahedral structure for $\mathrm{Zn}$ (II) complex.

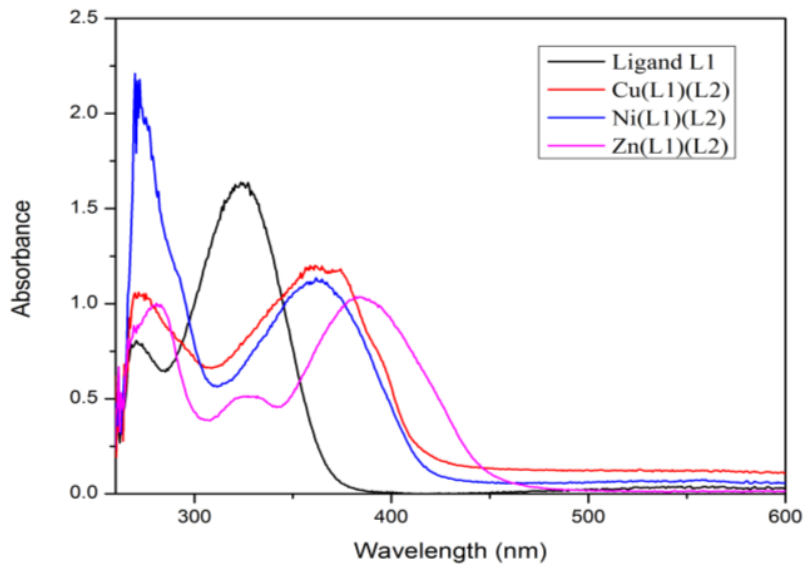

Figure 2. UV- Visible Spectra of the L1 and its Mixed Ligand Complexes. 
On the basis of the above characterizations, the probable structure of complexes are given below

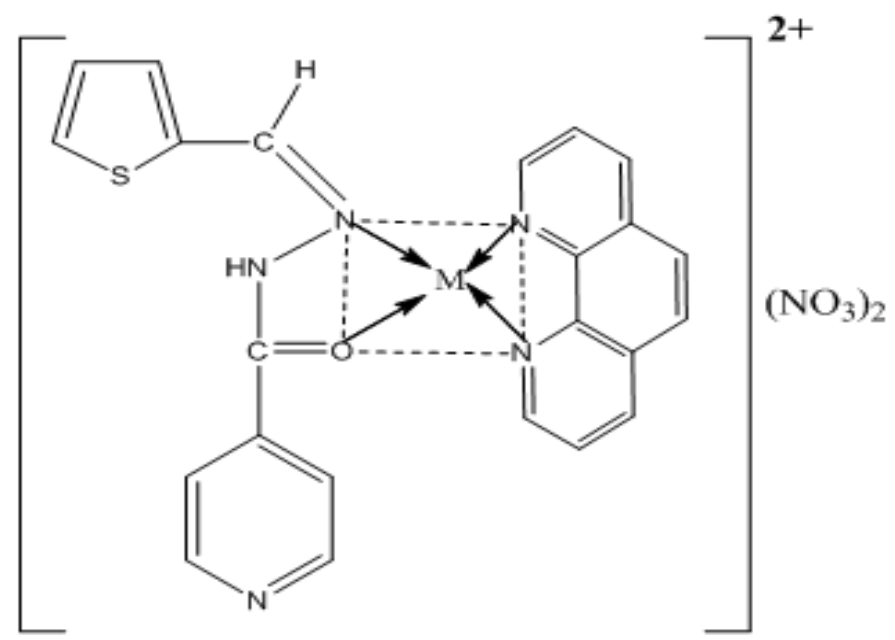

Figure 3. The proposed square planar geometry of $\mathrm{Cu}(\mathrm{II})$, and Ni(II)complexes.

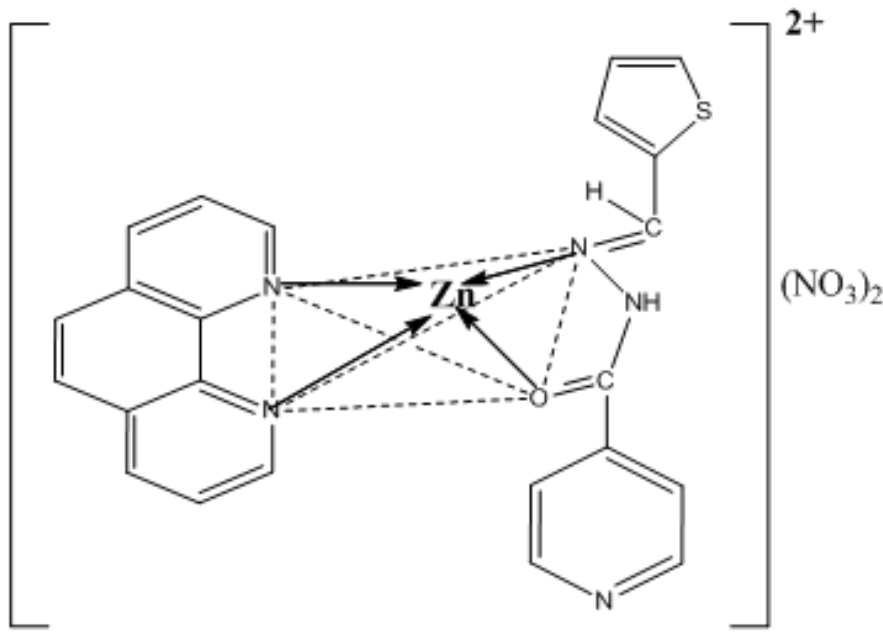

Figure 4. The proposed tetrahedral geometry of $\mathrm{Zn}(\mathrm{II})$ complex.

\section{Pharmacology}

\section{Antibacterial Activity}

The Schiff base ligands and its mixed ligand complexes were investigated for antibacterial activity against Escherichia coli and Pseudomonas sp. at the concentration $(100 \mu \mathrm{g} / 10 \mu \mathrm{L})$ in DMF. The values of inhibitory zone were measured in diameter $(\mathrm{mm})$ and the result of their antibacterial activity has been listed in Table 1 and shown in Fig. 5. The Schiff base ligands did not show any inhibition zone against the selected bacterial strains. Moreover, it was found that $[\mathrm{Zn}(\mathrm{L} 1)(\mathrm{L} 2)]\left(\mathrm{NO}_{3}\right)_{2}$ exhibited the highest antibacterial activity with the zone of inhibition ranging between 18 and $12 \mathrm{~mm}$ against Pseudomonas sp., and Escherichia coli. Overtone's concept and Tweedy's chelation theory can explain the greater activity of the complexes [44]

The significant antibacterial activity of metal complexes is due to the fact that only lipid-soluble materials making lipo-solubility, which is a main control factor for antibacterial activity. The polarity of metal ions is more reduced, due to overlap and the partial sharing of positive charge of the metal ion with the orbitals of the donor groups of the ligands. The metal ions are therefore, easily be adsorbed on the surface of the cell wall of the organisms and able to disrupt the respiratory process of the cells and blocks protein synthesis and consequently, limits the additional growth of organisms. Besides this, the substituent methyl group plays a vital role to increase the lipophilic nature of the metal complexes that is the reason for remarkable antibacterial activity and other factors like solubility, coordinating sites, the geometry of complexes, steric, concentration, and hydrophobicity having considerable influence on the antibacterial potency [44-46].

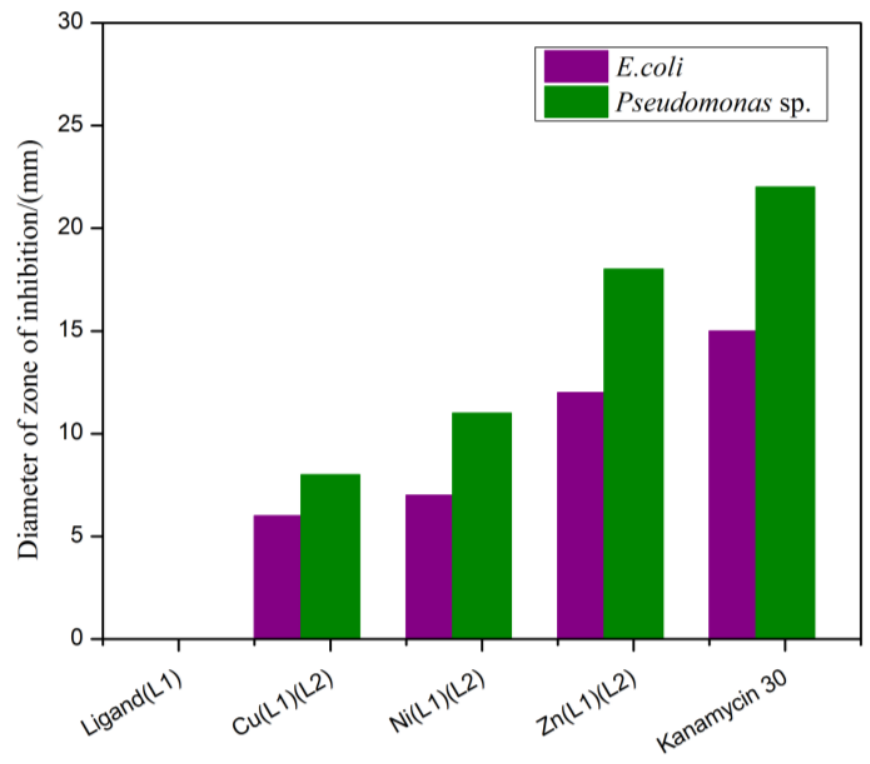

Figure 5. Graphical representation of antibacterial activity of ligand L1, L2, and its metal complexes against Escherichia coli and Pseudomonas sp. with kanamycin standard.

Table 1. Antibacterial activities of ligand L1, L2, and its metal complexes.

\begin{tabular}{|c|c|c|}
\hline \multicolumn{3}{|c|}{ Diameter of Zone of Inhibition $(\mathrm{mm})$ of tested compounds $(100 \mu \mathrm{g} / \mathrm{disc}$} \\
\hline \multirow{2}{*}{ Compounds } & \multicolumn{2}{|c|}{ Gram Negative } \\
\hline & Escherichia coli & Pseudomonas sp. \\
\hline Kanamycin $(30 \mu \mathrm{g} / \mathrm{disc})$ & 15 & 22 \\
\hline Ligand (L1) & - & - \\
\hline$[\mathrm{Cu}(\mathrm{L} 1)(\mathrm{L} 2)]\left(\mathrm{NO}_{3}\right)_{2}$ & 6 & 8 \\
\hline$[\mathrm{Ni}(\mathrm{L} 1)(\mathrm{L} 2)]\left(\mathrm{NO}_{3}\right)_{2}$ & 7 & 11 \\
\hline$[\mathrm{Zn}(\mathrm{L} 1)(\mathrm{L} 2)]\left(\mathrm{NO}_{3}\right)_{2}$ & 12 & 18 \\
\hline
\end{tabular}

\section{Antioxidant activity}

Antioxidant activity of the synthesized ligand and its mixed ligand complexes with was investigated by the free radical compound 2, 2-diphenyl-1-picryl hydrazyl (DPPH), and BHT (butylatedhydroxytoluene) as a standard at different concentrations $(20,40,60,80$, and $100 \mu \mathrm{g} / \mathrm{mL})$. DPPH having a violet color when dissolved in DMF, it became pale red [47]. The percentage of DPPH radical scavenging activity and $\mathrm{IC}_{50}$ values of $\mathrm{BHT}$, ligands, and its mixed ligand complexes has been listed in 2 and shown in Fig. 6-7. From the results, it is found that all the metal complexes displayed moderate DPPH radical scavenging activity than the Schiff base ligands comparable with BHT. Among all the tested compounds, $\mathrm{Cu}$ (II) complexes exhibited the highest antioxidant activity than $\mathrm{Ni}$ (II) and $\mathrm{Zn}$ (II) complexes as compared with the standard BHT.

Due to the coordination environment and redox properties, the difference in the antioxidant activity of the Schiff base metal complexes can be ascribed. Generally, the redox properties of the metal complexes depend on some factors including axial ligation, chelate ring size, and degree of unsaturation in the chelate ring [45, 46]. The high antioxidant activity of $\mathrm{Cu}(\mathrm{II})$ complexes compared to other prepared complexes is assigned to the high reducing ability of $\mathrm{Cu}^{2+}$ and its proton donation property where $\mathrm{Cu}^{2+}$ act as a super oxide scavenging center [48]. Ni(II) complexes showed moderate antioxidant activity, it could be due to steric hindrance by geometric structure, hindering the radical approach of DPPH to active complex centers. Furthermore, Zn(II) having lower activity because probably, $\mathrm{Zn}$ (II) ion is not a transition metal and therefore cannot participate in electron-transfer reactions [48]. 
Table 2. \% of Scavenging activity and $\mathrm{IC}_{50}$ values of BHT, ligand-L1, and its mixed ligand complexes

\begin{tabular}{|c|c|c|c|c|c|}
\hline $\begin{array}{c}\text { Conc. } \\
(\mu \mathrm{g} / \mathrm{mL})\end{array}$ & $\begin{array}{c}\% \\
\text { BHT }\end{array}$ & $\begin{array}{l}\% \\
\text { L1 }\end{array}$ & $\begin{array}{c}\% \\
{[\mathrm{Cu}(\mathrm{L} 1)(\mathrm{L} 2)]\left(\mathrm{NO}_{3}\right)} \\
2 \\
\end{array}$ & $\begin{array}{c}\% \\
{[\mathrm{Ni}(\mathrm{L1})(\mathbf{L} 2)]\left(\mathrm{NO}_{3}\right)} \\
\frac{2}{2} \\
\end{array}$ & $\begin{array}{c}\% \\
{[\mathrm{Zn}(\mathrm{L} 1)(\mathrm{L} 2)]\left(\mathrm{NO}_{3}\right)} \\
2 \\
\end{array}$ \\
\hline 20 & 11.29 & 5.50 & 22.87 & 16.35 & 1.59 \\
\hline 40 & 26.77 & 2.31 & 50.36 & 20.54 & 5.21 \\
\hline 60 & 34.97 & 3.16 & 61.36 & 24.27 & 6.22 \\
\hline 80 & 38.20 & 4.92 & 63.82 & 27.93 & 7.66 \\
\hline 100 & 39.65 & 6.14 & 65.22 & 30.37 & 8.24 \\
\hline $\mathrm{IC}_{50}$ & 105.71 & 793.65 & 61.88 & 139.66 & 510.20 \\
\hline
\end{tabular}

\section{DPPH Assay}

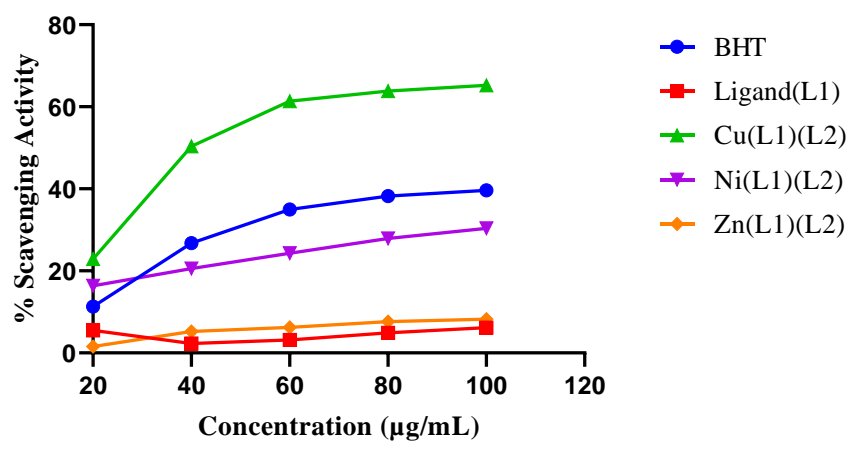

Figure 6. DPPH radical scavenging activity of the mixed ligand complexes of ligand-L1, and $\mathrm{L} 2$ at different concentrations $(20,40,60,80$, and $100 \mu \mathrm{g} / \mathrm{mL}$ with standard antioxidant BHT.

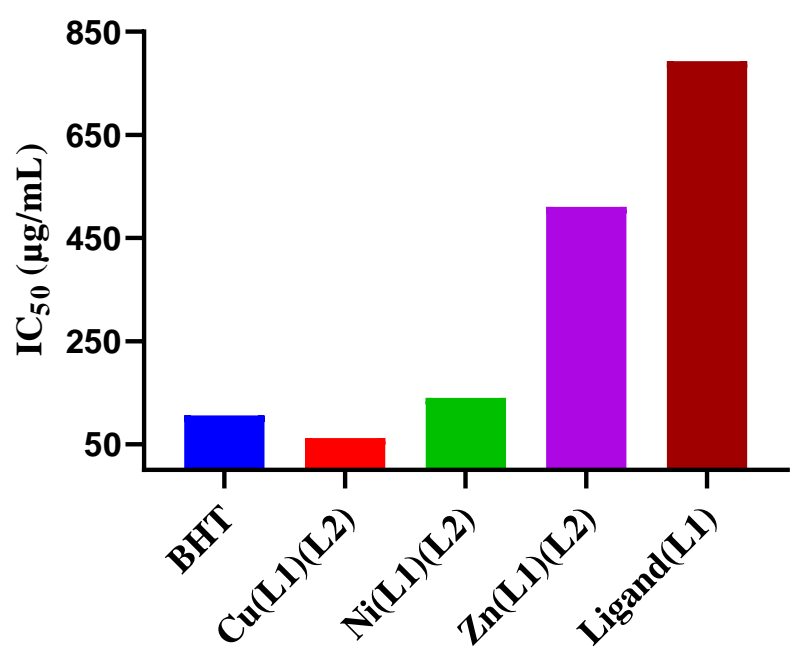

Figure 7. $\mathrm{IC}_{50}$ value of the mixed ligand complexes of ligand-L1, and $\mathrm{L} 2$ at different concentrations $(20,40,60,80$, and $100 \mu \mathrm{g} / \mathrm{mL}$ with standard antioxidant BHT.

\section{CONCLUSIONS}

The synthesis and characterization of isonicotinamido-thiophene-2carbaldimine and its $\mathrm{Cu}(\mathrm{II}), \mathrm{Ni}(\mathrm{II})$, and $\mathrm{Zn}$ (II) mixed ligand complexes with 1,10phenanthroline have been achieved with physicochemical and spectroscopic techniques. The value of conductivity indicated the electrolytic existence of the complexes. The IR spectral analysis leads to the conclusion that the ligands coordinated to central ions through $\mathrm{N}$ and $\mathrm{O}$ atoms. From the UV-Vis spectra and magnetic moment data, it is found that The coordination geometry around the metal ions (for $\mathrm{Cu}$ (II), and $\mathrm{Ni}$ (II) ions) can be described as square planar geometry and tetrahedral geometry for $\mathrm{Zn}$ (II) complex. Zn(II) complex showed maximum antibacterial activity compared to Schiff base and other complexes.
But it showed the lowest antioxidant activity than $\mathrm{Cu}(\mathrm{II})$, and $\mathrm{Ni}(\mathrm{II})$ complexes compared to the standard BHT.

\section{ACKNOWLEDGMENTS}

The authors are thankful to the Chairman, Department of Chemistry, University of Rajshahi, Bangladesh for the laboratory Facilities.

\section{CONFLICT OF INTEREST}

No conflict of interest was declared by the authors.

\section{REFERCENCES}

1. O.G. Idemudia, E.C. Crystals, "Spectroscopy, Crystal and Molecular Structures of New 4-Acylpyrazolone Dinitrophenylhydrazones". Crystals, 2016; 6: 127

2. G. Naganagowda, R. Meijboom, A. Petsom, "Synthesis and Antimicrobial Activity of New Schiff Base Compounds Containing 2-Hydroxy-4pentadecylbenzaldehyde Moiety”. Adva. Chem., 2014; 1-9

3. B.R. Thorat, P. Kamat, D. Khandekar, S. Lele, M. Mustapha, S. Sawant, R. Jadhav, S. Kolekar, R. Yamgar, R.G. Atram, "Synthesis and Fluorescence study of Novel Schiff Bases of Isoniazide". J. Chem. Pharm. Res., 2011; 3(6): 1109-1117.

4. Md. Saddam Hossain, C.M. Zakaria, Roushown Ali, Md. Kudrat-E-Zahan "Selected Pharmacological Applications of 1st Row Transition Metal Complexes: A review" Clin. Med. Res., 2017; 6(6): 177-191

5. W.L. Liu, Y. Zou, C.L. Ni, Y.Z. Li, Q.J. Meng, "Synthesis, structural characterization and magnetic properties of new tripeptide Schiff base heterotrinuclear $\mathrm{Cu}(\mathrm{II})-\mathrm{M}$ (II)-Cu(II) ( $\mathrm{M}=\mathrm{Ni}$ and $\mathrm{Mn}$ ) complexes". J. Molec. Struc., 2005; 751: 1-6

6. P. Przybylski, G. Bejcar, G. Schroeder, B. Brzezinski, "Complexes of Schiff base of gossypol with 5-hydroxy-3-oxapentylamine and some monovalent cations studied by ESI MS as well as PM5 semiempirical methods," J. Molec. Struc., 2003; 654(1-2): 245-252

7. R. Dreos, G. Nardin, L. Randaccio, P. Siega, G. Tauzher, V. Vrdoljak, "Synthesis, molecular structure, and characterization in solution of a new series of inorganic and organometallic Co(III) Schiff base complexes". Inorganica. Chimica. Acta, 2003; 349: 239-248

8. R.K.Mohapatra, P.K.Das, M.K.Padhan, M.El-Ajaly, D.Das, H.F.Salem, U.Mahanta, G.Badhei, P.K.Parhi, A.A.Maihub and Md.Kudrat-E-Zahan "Recent Advances in Urea- and Thiourea-Based Metal Complexes: Biological, Sensor, Optical, and Corroson Inhibition Studies" Comm. Inorg. Chem., 2019; 0:1-61

9. Md.Saddam Hossain, Md.Abdul Mannan, Md.Kudrat-E-Zahan "International Journal of Chemistry Studies Recent advances on microbial activity of metal complexes: A short review" Int. J. Chem. Stud., 2019; $4(1): 17-24$

10. M.T.H. Tarafder, K.B. Chew, K.A. Crouse, A.M. Ali, B.M. Yamin, H.K. Fun, "Synthesis and characterization of $\mathrm{Cu}(\mathrm{II}), \mathrm{Ni}(\mathrm{II})$ and $\mathrm{Zn}(\mathrm{II})$ metal complexes of bidentate NS isomeric Schiff bases derived from Smethyldithiocarbazate (SMDTC): bioactivity of the bidentate NS isomeric Schiff bases, some of their $\mathrm{Cu}$ (II), Ni(II) and $\mathrm{Zn}$ (II) complexes and the $\mathrm{x}$-ray structure of the bis[S-methyl- $\beta$ - $N$-(2-furylmethyl) methylenedithiocarbazato]zinc(II) complex". Polyhedron, 2002; 21(27-28): 2683-2690

11. L.H.A. Rahman, R.M.E. Khatib, L.A.E. Nassr, A.M.A. Dief, "DNA binding ability mode, spectroscopic studies, hydrophobicity, and in vitro antibacterial evaluation of some new Fe(II) complexes bearing ONO donors amino acid Schiff bases". Arabian J. Chem., $2013 . \quad$ DOI: doi.org/10.1016/j.arabjc.2013.07.010 
12. R.M. Ahmed, E.I. Yousif, M.J.A. Jeboori, “Co(II) and Cd(II) Complexes Derived from Heterocyclic Schiff-Bases: Synthesis, Structural Characterisation, and Biological Activity”. Scient. World J., 2013; 1-7. DOI: doi.org/10.1155/2013/754868

13. R. Radfard, A. Abedi, "Synthesis and Characterization of New Schiff Bases of Ethylenediamine and Benzaldehyde Derivatives, Along with Their Iron Complexes".J. Appli. Chem. Res., 2015; 9(2): 59-65.

14. E.I. Obasuyi, O. Iyekowa, "Synthesis, Characterization and Antimicrobial of Schfiff Base from 5-Bromo -Salicylaldehyde and P-Toluidine”. J. Appl. Sci. Environ. Manage, 2018; 22 (11): 1733-1736

15. Saud I. Al-Resayes, Mohammad Shakir, Nida Shahid, Mohammad Azam, Asad U. Khan, "Synthesis, spectroscopic characterization and in vitro antimicrobial studies of Schiff base ligand, H2L derived from glyoxalic acid and 1,8diaminonaphthalene and its $\mathrm{Co}(\mathrm{II}), \mathrm{Ni}(\mathrm{II}), \mathrm{Cu}(\mathrm{II})$ and $\mathrm{Zn}(\mathrm{II})$ complexes". Arab. J. Chem., 2013; http://dx.doi.org/10.1016/j.arabjc.2011.11.004

16. Mohammad Azam, Saud I. Al-Resayes, Agata Trzesowska-Kruszynska, Rafal Kruszynski, Ambarish Verma, Uttam K. Pati, "Chiral anionic binuclear zinc complexes based on diaminocyclohexane ligand and their in vitro antiproliferative studies". Inorg. Chem. Comm., 2014; 46: 73-80

17. Mohammad Azam, Saud I. Al-Resayes, Agata Trzesowska-Kruszynska, Rafal Kruszynski, Faiyaz Shakeel, Saied M. Soliman, Mahboob Alam, Mohammad Rizwan Khan, Saikh Mohammad Wabaidur, "Zn(II) complex derived from bidentate Schiff base ligand: Synthesis, characterization, DFT studies and evaluation of anti-inflammatory activity". J. Mol. Struct., 2020; 1201: 127177

18. Azam, M., Wabaidur, S.M., Alam, M. et al., Synthesis, characterization, cytotoxicity, and molecular docking studies of ampyrone-based transition metal complexes. Transit. Met. Chem., 2021: 46; 65-71

19. A.T. Chaviara, P.J. Cox, K.H. Repana, R.M. Papi, K.T. Papazisis, D. Zambouli, A.H. Kortsaris, D.A. Kyriakidis, C.A. Bolos, "Copper(II) Schiff base coordination compounds of dien with heterocyclic aldehydes and 2 amino-5-methyl-thiazole: synthesis, characterization, antiproliferative and antibacterial studies. Crystal structure of $\mathrm{CudienOOCl}_{2}$ ". J. Inorg. Biochem., 2004; 98: 1271-1283

20. Mohammad Azam, Saud I. Al-Resayes, Mahboob Alam, Agata TrzesowskaKruszynska, Rafal Kruszynski, Mohammed Rafiq H. Siddiqui., A new ladder-type dichloro(2,2-dimethyl-1,3-diaminopropane) copper complex:Synthesis, structural studies and selective sensing behavior towards a ketone molecule". Polyhedron, 2019; 170: 287-293

21. A.M.A. Omyma, "Palladium(II) and zinc(II) complexes of neutral [N2O2] donor Schiff bases derived from furfuraldehyde: Synthesis, characterization, fluorescence and corrosion inhibitors of ligands". Spectrochimica Acta Part A: Molec. Biomolec. Spect., 2014; 132: 52-60

22. K.P. Anoop, B. Abhishek, B. Vikas, D. Apoorva, "Structural, Electronic, and Vibrational Properties of Isoniazid and Its Derivative NCyclopentylidenepyridine-4-carbohydrazide: A Quantum Chemical Study".J. Theoreti. Chem., 2014; 1-15. DOI: 10.1155/2014/894175

23. R.N. Garner, C.G. Pierce, C.R. Reed, W.W. Brennessel, "Photoinitiated Treatment of Mycobacterium using Ru(II) Isoniazid Complexes. Inorganica. Chimica. Acta, 2017. DOI: 10.1016/j.ica.2017.02.031

24. R.I. Zubatyuk, L.I. Kucherenko, I.A. Mazur, O.V. Khromyleva, O.V. Shishkin, "A theoretical structural study of isoniazid complexes with thiotriazoline". Chem. Hetero. Comp. 2014; 50 (3): 476-482

25. L. Guilian, Z. Jingrui, J. Yi, Z. Li-li, L. Haican, L. Machao, Z. Xiuqin, W. Kanglin, "Cross-resistance of isoniazid, para-aminosalicylic acid and pasiniazid against isoniazid-resistant Mycobacterium tuberculosis isolates in China".J. Glob. Antimicro. Resist., 2020; 20: 275-281. DOI. 10.1016/j.jgar.2019.08.005

26. Imran, A.W. Waseem, S. Kishwar, "Empirical Formulae to Molecular Structures of Metal Complexes by Molar Conductance", Syn. React. Inorg. Metal-Org., Nano-Metal Chem.,T.F. G., 2013; 43(9); 1162-1170

27. L.D. Mariana, K. Angela, S. Nicoale, M.M. Adin "Transition metal M(II) complexes with isonicotinic acid 2-(9-anthrylmethylene)-hydrazide”. J. Serb. Chem. Soc., 2010; 75: 1515

28. N. Raman, R.J. Dhaveethu, A. Sakthivel. "Synthesis, spectral characterization of Schiff base transition metal complexes: DNA cleavage and antimicrobial activity studies". J. Chem. Sci., 2007; 119 (40): 303-310

29. C. Sulekh, K.G. Lokesh, J. Deepali. "Spectroscopic studies on Mn(II), Co(II), $\mathrm{Ni}(\mathrm{II})$, and $\mathrm{Cu}$ (II) complexes with $\mathrm{N}$-donor tetradentate (N4) macrocyclic ligand derived from ethylcinnamate moiety". Spectrochimi. Acta Part A, 2004; $60: 2411-2417$

30. L Mitu L, Mohamed N, Iqbal S, Raman N, Muhammad I, Sharma SK"Template Synthesis, Characterization and Biological Activity of $\mathrm{Cu}(\mathrm{II})$,
$\mathrm{Ni}(\mathrm{II}), \mathrm{Co}(\mathrm{II}), \mathrm{Zn}$ (II) Complexes with Isonicotinoylhydra”. E-J. Chem., 2010; 7(1): $227-233$

31. F. Afsan, S.A. Dalia, S. Hossain, S. Sarker, K.E. Zahan, "Synthesis, Spectral and Thermal Characterization of Selected Metal Complexes Containing Schiff Base Ligands with Antimicrobial Activities". Asian J. Chem. Sci., 2018; 4(3): 1-19

32. S.I.A. Resayes, M. Shakirb, A. Abbasi, K.M.Y. Amin, A. Lateef "Synthesis, spectroscopic characterization and biological activities of N4O2 Schiff base ligand and its metal complexes of $\mathrm{Co}(\mathrm{II}), \mathrm{Ni}(\mathrm{II}), \mathrm{Cu}(\mathrm{II})$ and $\mathrm{Zn}(\mathrm{II})$ ". Spectromica. Acta Part A, 2012; 93: 86-94

33. V. Arun, N. Sridevi, P.P. Robinson, S. Manju, K.K.M. Yusuff, "Ni(II) and $\mathrm{Ru}$ (II) Schiff base complexes as catalysts for the reduction of benzene". J. Mol. Catal. A : Chem., 2009; 304: 191-198

34. M.A. Riyadh, I.Y. Enaam, J.A.J. Mohamad. "Co(II) and Cd(II) Complexes Derived from Heterocyclic Schiff-Bases: Synthesis, Structural Characterisation, and Biological Activity". The Sci. World J., 2013; 1-6

35. Mohammad Azam, Sourabh Dwivedi, Saud I. Al-Resayes, S.F. Adil, Mohammad Shahidul Islam, Agata Trzesowska-Kruszynska, Rafal Kruszynski, Dong-Ung Lee, " $\mathrm{Cu}(\mathrm{II})$ salen complex with propylene linkage: An efficient catalyst in the formation of CeX bonds $\left(\mathrm{X}^{1 / 4} \mathrm{~N}, \mathrm{O}, \mathrm{S}\right)$ and biological investigations". J. Mol. Struc., 2017; 1130: 122-127

36. O.O. Kehinde, A.M. Micheal, K.V.S.N. Raju, N. Tadigoppula, "Structural and in vitro anti-tubercular activity study of (E)- $N$ '-(2,6dihydroxybenzylidene)nicotinohydrazide and some transition metal complexes". J. Iran Chem. Soc., 2015; 12: 815-829

37. O.O. Kehinde, A.A. Joseph, O.E.E. Cyril, O.S. Tolutope, K. Akinlolu, A.M Micheal, N. Tadigoppula "Transition Metal Complexes of $(E)-\mathrm{N}$ '-(4 cyanobenzylidene)nicotinohydrazide): Synthesis, Structural and AntiMycobacterial Activity Study”. J. Appli. Sci., 2015; 15 (10): 1210-1222

38. G.S. Kulkarni, P. L. Anandgaonker, D. D. Gaikwad, D.M. Janrao, “ Efficient ultrasound synthesis and biological screening of metal complexes of N-(4methoxybenzylidene) isonicotinohydrazone". World J. Pharma. Res., 2016; 5: $1153-1161$

39. I.P. Ejidike, P.A. Ajibade, "Synthesis, Characterization and Biological Studies of Metal(II)Complexes of (3E)-3-[(2-\{(E)-[1-(2,4-Dihydroxyphenyl) ethylidene]amino\}ethyl)imino]-1-phenylbutan-1-one Schiff Base Molecules, 2015; 20: 9788-9802. Doi:10.3390/molecules20069788

40. K.A.S. Rehab, T.N. Ahmed, M.A. Eman, "Synthesis, characterization and antimicrobial Evaluation of mixed ligand complexes of Manganese(II), cobalt(II), copper(II), nickel(II) and Mercury(II) with 1,10 phenanthroline and a Bidentateschiff base". Eur. Chem. Bull., 2016; 5(8): 335-338

41.P.E. Kechukwu , A.A. Peter, "Synthesis, Characterization and Biological Studies of Metal(II)Complexes of (3E)-3-[(2-\{(E)-[1-(2,4 Dihydroxyphenyl)ethylidene]amino \}ethyl)imino]-1-phenylbutan-1-one Schiff Base". Molecules, 2015; 20: 9788-9802. doi:10.3390/molecules20069788.

42. A.E. Kismat, H.M.Saddam, A.B.M. Nur, A.A.S.M. Zahid, K.M. Ranjan, M.A. Mannan, C.M. Zakaria, M.K.E. Zahan, "Synthesis, Spectral and Thermal Characterization on Bioactive Complexes of $\mathrm{Mg}(\mathrm{II}), \mathrm{Zn}$ (II), $\mathrm{Sn}$ (II), VO(II) and Bi(III) Ions Containing Schiff Base Ligand". J. Chem. Bio. Phy. Sci., 2019; 9(4): 201-218

43. Mohammad Shakir, Nida Shahid, Naushaba Sami, Mohammad Azam, Asad U. Khan, "Synthesis, spectroscopic characterization and comparative DNA binding studies of Schiff base complexes derived from 1-leucine and glyoxal". Spectrochimica Acta Part A., 2011; 82: 31-36

44. M.N. Patel, P.B. Pansuriya, P.A. Parmar, D.S. Gandhi, "Synthesis, characterization, and thermal and biocidal aspects of drug-based metal complexes". Pharma. Chem. J., 2008; 42(12): 687-692

45. V. Kadtala, G. Nirmala, D. Sreenu, K. Kumar, R. Krishnan, Shivaraj, "Crystal structure, DNA interactions, antioxidant and antitumor activity of thermally stable $\mathrm{Cu}(\mathrm{II}), \mathrm{Ni}(\mathrm{II})$ and $\mathrm{Co}(\mathrm{III})$ complexes of an $\mathrm{N}, \mathrm{O}$ donor Schiff base ligand". Poly., 2019: 171: 86-97

46. V. Sumalatha, R. Aveli, V. Narendrula, G. Nirmala, D. Sreenu, Shivaraj, "Synthesis, characterization, DNA binding propensity, nuclease efficacy, antioxidant and antimicrobial activities of $\mathrm{Cu}(\mathrm{II}), \mathrm{Co}$ (II) and $\mathrm{Ni}$ (II) complexes derived from 4-(trifluoromethoxy)aniline Schiffbases".Chem. Data Collect., 2019; 20:1-12

47. N. Nighat, A. Irshad, D. Nizam, W. Amjad, U-R. Sadeeq, S. Abdul, K. Farhan, K. Sher, P. Simon, U. Kamal, "Synthesis, Characterization and Antioxidant Activity of Nickel(II) Schiff Base Complexes Derived from 4(Dimethylamino)benzaldehyde". J. Chem. Soc. Pak. Chem. Soc. Pak., 2020; 42(2): 238-242

48. M. Saif, FE-S. Hoda, M.M. Mahmoud, F.E. Mohamed, A.I. Nabeel, R. Fouad, "Synthesis, characterization, and antioxidant/cytotoxic activity of new chromone Schiff base nanocomplexes of $\mathrm{Zn}(\mathrm{II}), \mathrm{Cu}(\mathrm{II}), \mathrm{Ni}(\mathrm{II})$ and Co(II)”. J. Molec. Struct., 2016. doi: 10.1016/j.molstruc.2016.03.060. 